Papers and Proceedings of the Royal Society of Tasmania, Volume 117, 1983.

(ms. received 18.5 .1982$)$

\title{
AN UNUSUAL OCCURRENCE OF ULTRAMAFIC AND MAFIC ROCKS NORTH OF MT BISCHOFF, NW TASMANIA
}

by P.R. Williams and $\Lambda . V$. Brown

Geological Survey of Tasmania

(with one table and one text-figure)

\section{ABSTRACT}

WILLIAMS, P.R. \& BROWN, A.V., 1983 (31 viii): An unusual occurrence of ultramafic and mafic rocks north of Mt Bischoff, NW Tasmania. Pap. Proc. R. Soc. Tasm., 117: 53-58. https://doi.org/10.26749/rstpp.117.53 ISSN 0080-4703. Department of Mines, Bligh Street, Rosny Park, Tasmania, Australia.

Plagioclase-bearing harzburgite, plagioclase lherzolite, basalt and dolerite intrude a sequence of mudstone, greywacke, pillowed basalt and chert in the Arthur River valley north of Mt Bischoff. The ultramafic rocks are concordant bodies characterised by absence of internal deformation structures, abundant primary mineral assemblages and cumulate textures. The ultramafics were most probably intruded as magma. Fine- to coarse-grained dolerite were intruded in the same zone, probably as dykes.

The dolerite is chemically and texturally distinct from pillowed basalt interbedded with the sedimentary sequence.

\section{INIRODUCTION}

Outcrops of ultramafic and mafic rocks in the Arthur River valley north of Mt Bischoff (fig. 1) were mapped during the Geological Survey of Tasmania's coverage of the St Valentine Quadrangle in northwestern Tasmania. The occurrence was previously unrecorded, as was much of the sedimentary and volcanic sequence of the surrounding countryside. The ultramafic rock bodies are unusual to Tasmania, in that they are apparently uncleformed, display their primary mineral compositions without extensive serpentinization and appear to intrude the surrounding sedimentary/volcanic sequence as sills. $\Lambda$ distinctive doleritic rock type intrudes the sedimentary/volcanic sequence in the same area as the ultramafic rocks. The purpose of this paper is to describe and contrast the igneous rock types in this unusual occurrence, and to compare the ultramafic rocks with those elsewhere in western Tasmania.

\section{GEOLOGICAL SETTING}

The area is underlain by a sequence of probable Eo-Cambrian or Early Cambrian greywacke, mudstone, basaltic lava, and subsidiary chert. These overlie the Proterozoic Nit Bischoff sequence with unconformity (Groves 1971). The proportion of mudstone, chert and greywacke to basaltic lavas varies considerably, and in places greywacke is absent and lava flows are separated by thin mudstone beds and minor chert. In the region of ultramafic rocks there is an approximately equal abundance of greywacke and mudstone, with more chert than usual and less basaltic lava. The sequence is continuous with the rock exposed in the Cleveland mine area (Cox and Glasson 1971; Collins 1981). The greywacke from the sequence in the Arthur River is very poorly sorted, composed of angular grains of feldspar, quartz and rock fragments. The rock fragments are metaquartzite, similar to quartzite from the Tyennan region metamorphic rocks of central Tasmania. The presence of detrital garnet grains as well as metaquartzite suggests a lyennan source area. Garnet has not been reported from Proterozoic rocks in northwestern lasmania. Detrital muscovite and biotite are also present. Chert interbedded with the mudstone and greywacke is usually finely-laminated often with well-preserved fine undulations, suggesting that it is a 


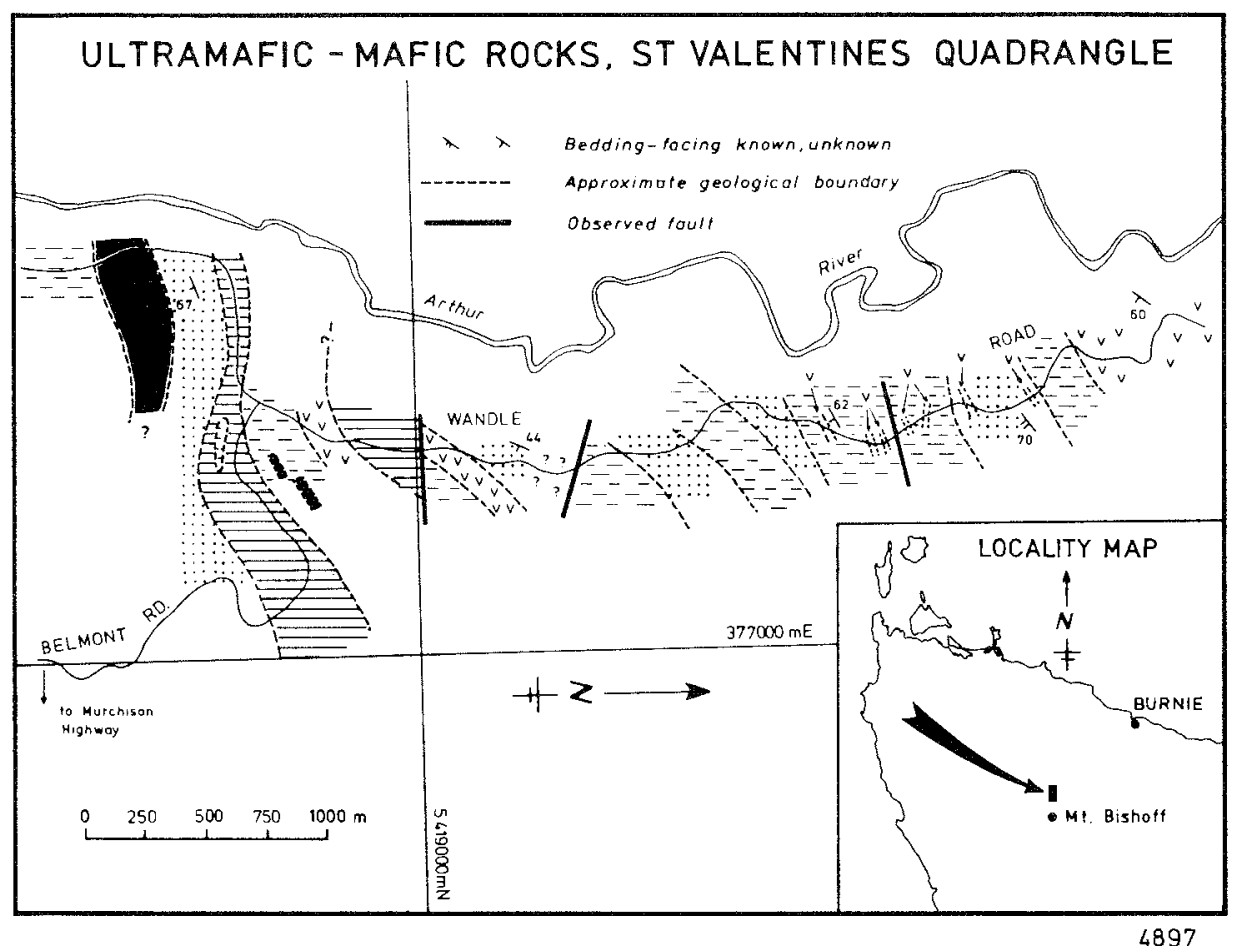

FIG. 1. - Geological map of the area around Belmont Road and Wandle Road in the Arthur River valley. Horizontal dashes indicate mudstone, dots indicate greywacke and chert, $v^{\prime} s$ indicate pillowed basalt, heavy horizontal lines indicate intrusive basalt and dolerite, and black areas indicate ultramafic rocks. Inset map shows location of the area, accessible via Belmont Road from the Murchison Highway.

primary deposit. There is no evidence of detrital grains, implying that the chert may have been a chemical sediment.

\section{BASALTIC ROCKS INTERBEDDED WITH THE SEDIMENTARY SEQUENCE}

Basaltic rocks in the sequence increase in abundance to the north. The basalts form pillow structures (Groves and Solomon 1964) and several exposures of pillow structure are observable on new Forestry roads in the area. Cusps of pillows are often filled with chert. In addition basaltic lapilli tuff is present, composed of rounded fragments of basalt in a fine-grained dark-coloured matrix with abundant pyroxene crystals (crystal lithic lapilli tuff). The basalt is typically an equigranular or porphyritic rock with smal1 phenocrysts of plagioclase and pyroxene in a matrix of feldspar laths, pyroxene crystals and chlorite showing an intersertal texture. The mineralogy and texture of these rocks has been described in detail by Groves and Solomon (1964). Chemical analyses of the basalt and tuff are shown in table 1 (analyses 1-4). 
TABLE 1

CHEMICAL ANALYSES

\begin{tabular}{|c|c|c|c|c|c|c|c|c|c|c|c|c|}
\hline & $\begin{array}{c}1 \\
783165^{*}\end{array}$ & $\begin{array}{c}2 \\
814513\end{array}$ & $\begin{array}{c}3 \\
783164\end{array}$ & $\begin{array}{c}4 \\
814514\end{array}$ & $\begin{array}{c}5 \\
814515\end{array}$ & $\begin{array}{c}6 \\
814512\end{array}$ & $\begin{array}{c}7 \\
783163\end{array}$ & $\begin{array}{c}8 \\
814511\end{array}$ & $\begin{array}{c}9 \\
813140\end{array}$ & $\begin{array}{c}10 \\
814510\end{array}$ & $\begin{array}{c}11 \\
814507\end{array}$ & $\begin{array}{c}12 \\
814508\end{array}$ \\
\hline $\mathrm{SiO}_{2}$ & 46.6 & 47.44 & 50.0 & 47.80 & 50.97 & 49.55 & 50.3 & 52.69 & 38.48 & 38.64 & 40.38 & 40.84 \\
\hline $\mathrm{TiO}_{2}$ & 1.7 & 3.38 & 1.0 & 1.95 & 0.25 & 0.39 & 0.39 & 0.55 & 0.03 & 0.03 & 0.04 & 0.05 \\
\hline $\mathrm{Al}_{2} \mathrm{O}_{3}$ & 14.2 & 12.31 & 13.3 & 13.26 & 13.56 & 14.15 & 14.0 & 13.26 & 4.41 & 4.34 & 5.42 & 5.40 \\
\hline $\mathrm{Fe}_{2} \mathrm{O}_{3}$ & 3.3 & 9.15 & 2.5 & 3.09 & 3.55 & 3.78 & 3.1 & 5.54 & 5.23 & 3.47 & 3.12 & 3.02 \\
\hline $\mathrm{FeO}$ & 9.2 & 4.67 & 8.0 & 9.68 & 7.41 & 7.10 & 6.9 & 7.41 & 5.28 & 5.51 & 5.81 & 6.49 \\
\hline MnO & 0.22 & 0.27 & 0.19 & 0.18 & 0.18 & 0.18 & 0.20 & 0.19 & 0.15 & 0.16 & 0.17 & 0.16 \\
\hline $\mathrm{MgO}$ & 7.5 & 5.54 & 8.2 & 6.34 & 6.79 & 7.55 & 7.7 & 5.00 & 31.89 & 32.94 & 31.04 & 32.42 \\
\hline $\mathrm{CaO}$ & 9.7 & 7.89 & 9.1 & 8.83 & 10.27 & 8.65 & 8.6 & 6.34 & 4.26 & 4.05 & 4.11 & 4.15 \\
\hline $\mathrm{Na}_{2} \mathrm{O}$ & 2.8 & 3.39 & 2.2 & 3.33 & 3.83 & 2.82 & 3.7 & 5.18 & $<0.03$ & 0.10 & 0.07 & 0.21 \\
\hline $\mathrm{K}_{2} \mathrm{O}$ & 1.0 & 0.86 & 0.53 & 0.22 & 0.34 & 0.21 & 0.28 & 0.17 & 0.03 & 0.07 & 0.06 & 0.07 \\
\hline $\mathrm{P}_{2} \mathrm{O}_{5}$ & 0.07 & 0.36 & 0.16 & 0.21 & 0.05 & 0.06 & 0.03 & 0.07 & 0.01 & 0.02 & 0.02 & 0.03 \\
\hline Loss & 4.06 & 3.67 & 4.80 & 4.10 & 3.37 & 4.77 & 4.60 & 2.65 & 9.86 & 9.68 & 8.87 & 6.62 \\
\hline $\mathrm{Cr}$ & 171 & 146 & 289 & 153 & 81 & 295 & 258 & 81 & 3698 & 4249 & 4903 & 4363 \\
\hline $\mathrm{Ni}$ & 103 & 79 & 106 & 92 & 73 & 104 & 119 & 63 & 1621 & 1703 & 1616 & 1657 \\
\hline $\mathrm{Rb}$ & 20 & 8 & 12 & 4 & 10 & 5 & 4 & $<4$ & $<4$ & $<4$ & 4 & 6 \\
\hline $\mathrm{Sr}$ & 484 & 288 & 147 & 222 & 107 & 171 & 226 & 210 & 27 & 15 & 21 & 28 \\
\hline Y & 22 & 33 & 25 & 20 & 8 & 14 & 15 & 18 & $<4$ & $<4$ & $<4$ & $<4$ \\
\hline $\mathrm{Zr}$ & 111 & 216 & 80 & 111 & 9 & 17 & $<5$ & 22 & 4 & $<4$ & $<4$ & $<4$ \\
\hline $\mathrm{Mg}$ & 52 & 43 & 59 & 47 & 55 & 56 & 59 & 42 & 85 & 87 & 87 & 86 \\
\hline $\mathrm{Ti} / \mathrm{Zr}$ & 92 & 94 & 75 & 105 & 166 & 317 & 468 & 150 & 45 & 45 & 60 & 75 \\
\hline $\mathrm{Ti} / \mathrm{Y}$ & 463 & 614 & 240 & 585 & 187 & 39 & 156 & 183 & 45 & 45 & 60 & 75 \\
\hline $\mathrm{Zr} / \mathrm{Y}$ & 5.05 & 6.55 & 3.2 & 5.55 & 1.13 & 1.21 & 0.33 & 1.22 & 1 & 1 & 1 & 1 \\
\hline $\mathrm{Cr} / \mathrm{Ni}$ & 1.66 & 1.85 & 2.73 & 1.66 & 1.11 & 2.49 & 2.17 & 1.29 & 2.28 & 2.50 & 2.53 & 2.63 \\
\hline
\end{tabular}

Analyses 1-4: Basaltic rocks from within the sedimentary sequence. 5-8: Fine-grained intrusive rocks.

9-10: U1tramafic body, Wandle Road.
11-12: U1tramafic body, Belmont Road.

* Sample numbers - Department of Mines analytical numbers.

Analysts: J. Furst and R. Roby, Department of Mines Laboratories, Launceston. 


\section{INTRUSIVE ROCKS}

Near the intersection of Belmont Road and Wandle Road, two major intrusions of ultramafic rock and one major intrusion of mafic (doleritic) rock have been identified (figure 1). In addition there are several intrusions or extrusions of basalt between the two ultramafic bodies. The mafic and ultramafic rocks occur in the same zone, but no age relationship between them has been observed. The southern ultramafic body is regionally concordant, and where contacts with sedimentary rocks are exposed these parallel bedding. However, the northern ultramafic body has a faulted northern margin, and the surrounding mudstone is highly fractured. These fractures are filled with quartz and very iron-rich chlorite (with second order birefringence colours) and post-date cleavage. The fault is inferred to be Devonian in age, because the cleavage probably formed during a Devonian deformation event.

On the southern edge of the southern ultramafic body there is a sequence of graded contact metamorphosed greywacke beds with pelitic tops. The pelitic tops are spotted, and the spots are deformed into lozenges parallel to cleavage, implying that metamorphism occurred prior to deformation. There are no nearby dolerite dykes or pillow lavas. The metamorphism of the country rock, and absence of any deformation features suggesting solid state movement in the ultramafics is used to infer that the ultramafics intruded as a liquid-dominated magma. However, poor exposure away from road sections does not allow a metamorphic aureole to be mapped out. The spotting and grading define the sedimentary facing of the sequence, which is to the north in this area.

In the area between the two major ultramafic bodies smaller intrusions of ultramafic rock (about $30 \mathrm{~m}$ thick) are concordant with a sequence of indurated chert and mudstone with incipient metamorphic spotting and biotite development. The sequence includes basalt with mudstone xenoliths. The sedimentary rocks have been brecciated and the fractures filled with opaque minerals.

The weight of evidence, therefore, strongly suggests that the ultramafic rocks were intruded as magma into the chert-greywacke-mudstone-pillowed basalt sequence. Later faulting has occurred along some primary boundaries, but other boundaries are undisturbed.

Mafic rocks have also been intruded into the sedimentary sequence (figure 1). The body of dolerite south of the ultramafic rocks cross-cuts the chert sequence in that area at a low angle. Several small areas of porphyritic, fine- and medium-grained dolerite occur in the area between the two ultramafic intrusions and one large outcrop has a discordant boundary. At one of these localities fine-grained dolerite, in continuity with the medium-grained dolerite, may represent a chilled margin. They are inferred to be dykes, although the possibility that some may be sills cannot be ruled out. The age relationship between the dolerite and ultramafic rocks cannot be determined, although intruded into the same area.

The intrusive rocks range in texture from basaltic, with a grainsize of about $0.02 \mathrm{~mm}$, up to doleritic rocks, with a grainsize of about $2 \mathrm{~mm}$. Rare gabbroic rocks are present. The basaltic rocks are composed of patches of chlorite, large pyrite grains, abundant small anhedral grains of pyroxene which tend to aggregate in patches in a matrix of altered laths of plagioclase. These are much more altered rocks than the basalt interbedded with the sedimentary rocks, and the presence of fine-grained granular aggregates of small pyroxene grains has not been observed in the pillowed basalt. Rare altered feldspar phenocrysts (plagioclase) are present and rare augite posettes also occur. Very finegrained rocks contain abundant phenocrysts of plagioclase. Some calcite veins are also present.

In contrast the coarse-grained intrusive varieties contain subhedral augite crystals in a matrix of truncated feldspar laths (intergranular texture). Large chlorite phenocrysts with prismatic habit are clearly pseudomorphs after another ferromagnesian mineral. Other specimens tend to ophitic to sub-ophitic and tremolite occurs as fibrous aggregates in anhedral patches. Rocks of intermediate grainsize show near anhedral pyroxene. 
P.R. WilTiams and A.V. Brown

Very altered specimens are common and are composed dominantly of chiorite and feidspar (albite) with abundant opaque minerals. The rocks exhibit thick tremolite veins, fresh albite veins and sericitic patches. The absence of this type of alteration in the basaltic lava flows in the sedimentary rocks suggests that it may be primary or deuteric alteration. Chemical analyses of these mafic rocks are shown in table 1 (analyses 5-8).

The ultramafic bodies grade from plagioclase and clinopyroxene bearing granular harzburgite at the top of the bodies to plagioclase bearing poikilitic lherzolite at the base. Overall the bodies are massive with little grainsize variation. The bases are coarser than the tops and contain a larger percentage of euhedral crystals.

Olivine and accessory chrome spinel are the cumulate mineral phases while pyroxene and plagioclase are post-cumulate. No indication of layering or of mineral fabric (foliation) is seen. The distribution of plagioclase is irregular. In places, olivine crystals are mantled by mesh serpentine group minerals and outlined by fine-grained magnetite. Interstitial highly altered plagioclase usually forms as cuspate patches but occasional fresh subhedral grains are seen.

In the northern part of the largest body, exposed along Wandle Road, the plagioclasebearing harzburgite has a panidiomorphic granular texture of rounded olivine and euhedral chrome spinel grains surrounded by anhedral post-cumulate granular orthopyroxene with minor irregular patches of clinopyroxene and plagioclase. Olivine and orthpyroxene make up approximately $95 \%$ of the rock.

Southwards the olivine grains become coarser and more euhedral, pyroxene remains dominantly granular but some orthopyroxene grains poikilitically enclose olivine. Postcumulate plagioclase is more common. The southernmost outcrop of this body consists of plagioclase bearing poikilitic lherzolite. Olivine crystals are subhedral to euhedral and both orthopyroxene and clinopyroxene poikilitically enclose olivine and chrome spinel grains as well as occurring as anhedral intergranular grains.

The second body, exposed along Belmont Road, is similar to the basal part of the Wandle Road body but contains a greater percentage of post-cumulate plagioclase and is slightly coarser-grained. Overall, euhedral to subhedral olivine crystals are poikilitically enclosed by anhedral pyroxene crystals. Chemical analyses of rocks from the ultramafic bodies are shown in table 1 (analyses 9-12).

Ultramafic bodies from western Tasmania are usually layered and the constituent minerals show plastic to solid state deformation characteristics. Neither of these features is found in the ultramafic rocks of the Wandle Road-Belmont Road area. All other Tasmanian ultramafic bodies have undergone a high degree of serpentinization and usually consist of disseminated blocks within a sheared serpentinite sheath. No such features are found associated with the Wande Road-Belmont Road bodies.

The nearest body of ultramafic rocks to the Wandle Road-Belmont Road area is the Heazlewood River Complex (Rubenach 1973). Plagioclase-bearing harzburgite and lherzolite from this complex are usually interlayered with other ultramafic rock types. They consist dominantly of rounded to elongate anhedral olivine grains poikilitically enclosed by large subhedral grains of orthopyroxene. Plagioclase is either subhedral with an intergranular texture or post-cumulate and interstitial to the olivine and pyroxene crystals. Olivine grains are partly to completely replaced by serpentine-group minerals and plagioclase is replaced by saussurite or hydrogrossular (Rubenach 1973).

\section{SUMMARY}

The sequence of mudstone, greywacke, chert and pillowed basalt exposed from along the Arthut River valley for $14 \mathrm{~km}$ north just north of Mt Bischoff is intruded by both ultram mafic and mafic rocks. It is probable that the ultramafic rock intruded as magma, which caused thermal metamorphism of the surrounding sedimentary rocks. Boundary faults present appear to be Devonian in age, but the absence of internal deformation structures and 
extensive serpentinization suggests that they have not moved significantly from their intrusive position.

Dolerite intrudes the sedimentary/volcanic sequence probably as dykes and differs significantly from the pillowed basalts in that it has lower $\mathrm{Zr}, \mathrm{Y}$ and $\mathrm{TiO}_{2}$ contents and different textural features. The intrusive rocks are also more altered.

\section{ACKNOWLEDGEMENTS}

Dr N. Farmer critically read the manuscript and made useful suggestions. The paper is published with permission of the Department of Mines.

\section{REFERENCES}

Collins, P.L.F., 1981: The geology and genesis of the Cleveland tin deposit, western Tasmania: fluid inclusion and stable isotope studies. Econ. Geol., 76: 365-392.

Cox, R. and Glasson, K.R., 1971: Economic geology of the Cleveland mine, Tasmania. Econ. Geol., 66: 861-878.

Groves, D.I., 1971: The regional significance of the Don Hill fault zone of Mt Bischoff, Tasmania. Tech. Rept Dept Mines Tasm., 14: 7-15. and Solomon, M., 1964: The geology of the Mt Bischoff district. Pap. Proc. R. Soc. Tasm., 98: 1-22.

Rubenach, M., 1973: THE TASMANIAN ULTRAMAFIC-GABBRO AND OPHIOLITE COMPLEXES. UnPubl. Ph.D. thesis, Univ. of Tasm.: Hobart. 